\title{
Spatial and Temporal Variations of Heavy Metal Pollution in Sediments of Daning River Under the Scheduling of Three Gorges Reservoir
}

\author{
Li-jing WANG ${ }^{1, a}$, Ze-bin TIAN ${ }^{1,2, b}$, Hong LI $^{1, c}$, Jia CAI ${ }^{1,3, d}$, Shan-jun WANG ${ }^{1, e}$ \\ 1.State Environmental Protection Key Laboratory of Drinking Water Source Protection, Chinese \\ Research Academy of Environmental Sciences, Beijing 100012, China \\ 2.College of Water Sciences, Beijing Normal University, Beijing 100875, China \\ 3. College of Hydroelectric and Environmental Engineering, China Three Gorges University, Hubei \\ Yichang, 443002, China \\ awanglj@craes.org.cn., ${ }^{b}$ tianzebin@hotmail.com, ${ }^{c}$ lihong927@hotmail.com, \\ d2791490990@qq.com, ${ }^{e} 155105861 @ q q . c o m$
}

Keywords: Three Gorges Reservoir; Scheduling; Sediments; Heavy metal; Spatial and temporal distribution; Vertical distribution.

Abstract. In order to explore the influence of Three Gorges Reservoir (TGR) operation on heavy metal pollution of sediment in tributaries, taking Daning river as a case study area, the variation characteristics of heavy metal distributions (in sections of DC, BSH, CZB, Yangtze River) were investigated, and the potential ecological hazards were evaluated by potential ecological risk index.The results showed that the average contents of $\mathrm{Cr}, \mathrm{Cu}, \mathrm{As}, \mathrm{Cd}$ and $\mathrm{Pb}$ were 116.782, 92.676, 19.877, $1.168,46.194 \mathrm{mg} / \mathrm{kg}$, respectively. The contents of the studied five kinds of heavy metals in sediment were ranked as follows: $\mathrm{Cr}>\mathrm{Cu}>\mathrm{Pb}>\mathrm{As}>\mathrm{Cd}$, and exceeded the background value by 1.23, 3.31, $1.61,6.79,1.16$ times, respectively. Spatial distributions of the five heavy metals had accumulated along the Daning river from upstream to downstream with the maximum contents in CZB. Temporal distributions of the five heavy metals showed that the higher content levels appeared after water release (drainage) from the TGR. Vertical distributions of the five heavy metals showed an increasing trend from the surface to the bottom at the period before and after drainage and high water level period, while showed a decreasing trend from the surface to the bottom at the impounding period. The potential ecological risk indexes of the five heavy metals ranked as follows: $\mathrm{Cd}>\mathrm{As}>\mathrm{Cu}>\mathrm{Pb}>\mathrm{Cr}$. $\mathrm{Cd}\left(E_{r}^{i}\right.$ was 115 1133) was the major pollutant in 4 sites, which showed a high level of risk. Correlation analysis showed a highly significant correlation between $\mathrm{Cu}, \mathrm{As}, \mathrm{Cd}$ and $\mathrm{Pb}$, which indicated that they may have the similar sources.

\section{Introduction}

It has been well documented that the impoundment of the Three Gorges Reservoir results in drastic hydrology and hydrodynamics alterations in the reservoir, which led to serious environmental problems in the backwater of tributaries ${ }^{[1-3]}$ concerning the slow flow velocity, the weakness of river transport capacity, and the accumulation of pollution. Since the impounding of the Three Gorges Reservoir, the water level increases significantly. Therefore, nutrients and toxic and harmful substances in soils of the water level fluctuation zone and the shore transport into river waters through the dissolution, exchange and diffusion, which has threaten the safety of the river water quality and results in potential ecological risks $^{[4]}$. As serious pollutants, heavy metals have potential harm to the natural environment ${ }^{[6,7]}$ because of their toxicity, persistence, non-degradability in the environment and easy to enrich in the water, soil and biology ${ }^{[5]}$. The heavy metals can pose severe threats to human health and ecological environment when their contents enrich to some extent ${ }^{[8]}$. As the accumulation base of heavy metals in water environment, sediment can reflect the impact of natural environment and human activities in a river basin, and is an important factor to measure the quality of water environment ${ }^{[9]}$. Studies have shown 
that $\mathrm{Pb}, \mathrm{Cu}, \mathrm{Cd}, \mathrm{As}, \mathrm{Cr}$ and inorganic mercury exhibit a tendency to increase after the impounding of the Three Gorges Reservoir, and the contents are high than those before the impounding of the Three Gorges Reservoir ${ }^{[10,11]}$. The regular fluctuation of water level in the Three Gorges Reservoir may result in the corresponding alternations of the extent of heavy metals enrichment in the tributaries ${ }^{[11-14]}$. At present, the researches related to heavy metals in the Three Gorges Reservoir are mainly concentrated in the distributions and ecological risk assessment of heavy metals in water soil and sediment $^{[15-17]}$, dynamic simulation of heavy metals between water in the water level fluctuation zone and soil ${ }^{[18]}$, distributions of heavy metals before and after the impoundment of the Three Gorges Reservoir $^{[12,19]}$. In particular, to date, the heavy metal pollution and assessment in sediments under different operation scheduling of Three Gorges Reservoir after the impoundment have been overlooked.

In this study, considering of operation schedule of Three Gorges Reservoir, we analyzed the spatial, vertical and temporal variation characteristics of heavy metals $(\mathrm{Cr}, \mathrm{Cu}, \mathrm{As}, \mathrm{Cd}, \mathrm{Pb})$ in sediments of Daning river and Yangtze River in different operation period (the drainage period: April to June, the impounding period: September to November, the high water level period: December to March), and assess the heavy metal pollution in sediments using the potential ecological risk index method, so as to provide data base and scientific basis to the water pollution prevention in tributaries of Three Gorges Reservoir.

\section{Materials and Methods}

Field sampling. Considering the influence of different operation scheduling of Three Gorges Reservoir on the distributions of heavy metals in Daning river, four surveys were carried out on April 9, 2012 (the period before drainage), June 9, 2012 (the period after drainage), November 8, 2012 (impounding period), January 19,2013 (high water level period) (Fig.1a) Four typical sampling sites were selected from the end of the backwater of Daning river to the confluence of the Yangtze River, followed by DC, BSH, CZB and Yangtze River (Fig.1b).

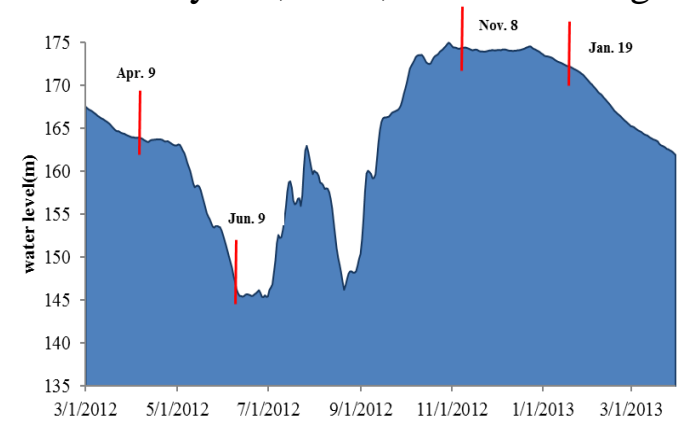

(a)

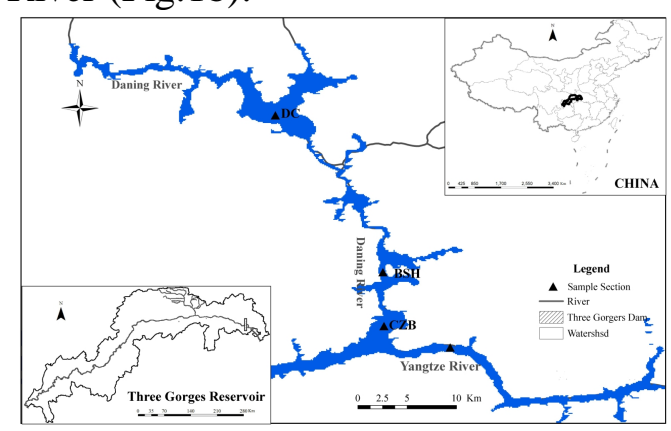

(b)

Fig.1(a)The scheduling of TGR and sampling time. Fig.1 (b) Map of Daning river and the sediment sampling sites

Sample collection measuring method. During the study period, at each site, sediment cores were collected by columnar collector. Immediately after collection, the sediment cores were divided into 5 $\mathrm{cm}$ slices in sequence, followed by the surface layer layer $(0 \sim 5 \mathrm{~cm})$, middle layer $(5 \sim 10 \mathrm{~cm})$, bottom layer $(10 \sim 15 \mathrm{~cm})$, and stored in precleaned polyethylene bags. Remove the stones, animal and plant residues and other foreign matter in each sediment sample after natural air-drying. Then, the sediment samples were passed through a 100-mesh sieve after grinding. The sediment samples were digested with $\mathrm{HCl}-\mathrm{HNO}_{3}-\mathrm{HF}$ and used for $\mathrm{Cr}, \mathrm{Cu}, \mathrm{As}, \mathrm{Cd}, \mathrm{Pb}$ measurements. The elements were measured by atomic absorption spectroscopy(SOLAAR M6 type atomic absorption spectrophotometer, American Thermo Company). Method blank, three groups of parallel samples, standard sediment materials GSD-10 (GBW 07312) were used to control data quality.

The evaluation method of Heavy metals pollution. The potential ecological risk index method, which was introduced originally by Hakanson in 1980, could be used to evaluate the ecological risk by calculating the potential ecological risk index (RI) and comparing between the content of the toxic 
pollutant and the background value ${ }^{[20]}$. It covered the comprehensive contents of environmental chemistry, biological toxicology and ecology. The RI was defined as Eq.1.

$$
\mathrm{RI}=\sum_{i=1}^{m} E_{r}^{i}=\sum_{i=1}^{m}\left(T_{r}^{i} \times \frac{C_{s}^{i}}{C_{n}^{i}}\right)
$$

where $C_{s}{ }^{i}$ is the heavy metal contents measured in the sediment samples, $C_{n}{ }^{i}$ is the reference background value of the heavy metal $i, T_{r}^{i}$ is the biological toxicity factor for a given substance. $E_{r}^{i}$ is the monomial potential ecological risk factor. $R I$ is the Integrated ecological risk index of soil or sediment of heavy metals.

The evaluation criteria of the potential ecological risk index method are listed in Table 1.

Table.1 Standards for the potential ecological risk of heavy metal pollutions

\begin{tabular}{cccccc}
\hline$E_{r}^{i}$ & $<40$ & $40 \sim 80$ & $80 \sim 160$ & $160 \sim 320$ & $>320$ \\
\hline$R I$ & $<150$ & $150 \sim 300$ & $300 \sim 600$ & $600 \sim 1200$ & $>1200$ \\
$\begin{array}{c}\text { Pollution } \\
\text { degree }\end{array}$ & low & moderate & high & very high & $\begin{array}{c}\text { extremely } \\
\text { high }\end{array}$ \\
\hline
\end{tabular}

\section{Results and Discussion}

The heavy metals contents in sediments Variations. The contents of all the five heavy metals in each sampling site are shown in Tab. 2. Results showed that the content ranges of the heavy metals were: $\mathrm{Cr}$, $43.380 \sim 269.146 \mathrm{mg} / \mathrm{kg}$; $\mathrm{Cu}, 28.488 \sim 238.150 \mathrm{mg} / \mathrm{kg}$; As, $10.724 \sim 33.168 \mathrm{mg} / \mathrm{kg}$; Cd, 0.576 5.667 $\mathrm{mg} / \mathrm{kg} ; \mathrm{Pb}, 15.386 \sim 169.158 \mathrm{mg} / \mathrm{kg}$, respectively. The average contents of $\mathrm{Cr}, \mathrm{Cu}, \mathrm{As}, \mathrm{Cd}$ and $\mathrm{Pb}$ in the samples were $116.782 \mathrm{mg} / \mathrm{kg}, 92.676 \mathrm{mg} / \mathrm{kg}, 19.877 \mathrm{mg} / \mathrm{kg}, 1.168 \mathrm{mg} / \mathrm{kg}, 46.194 \mathrm{mg} / \mathrm{kg}$, respectively, ranking in decreasing order as follows, $\mathrm{Cr}>\mathrm{Cu}>\mathrm{Pb}>\mathrm{As}>\mathrm{Cd}$. The heavy metal contents in sediments of the samples all reached the second grade standard of soil environment quality standard ( GB15618-1995). In particular, the Cd pollution was more serious, and the content was more than 1.1 times of the value of three grade standard. Compared with the background value of sediment in Yangtze River, the contents of heavy metals in sediments showed significant cumulative effect and exceeded the background value by $1.23,3.31,1.61,6.79,1.16$ times, respectively. In addition, the Cd and $\mathrm{Cu}$ had accumulated to the highest extent, which indicated that there were exogenous inputs of $\mathrm{Cd}$ and $\mathrm{Cu}$ in Daning river, and the pollution situation should not be underestimated (Table.2).

Table. 2 Contents of heavy metals in sediments

\begin{tabular}{|c|c|c|c|c|c|c|}
\hline \multirow{2}{*}{ sampling site } & \multirow{2}{*}{ Items } & \multicolumn{5}{|c|}{ contents of heavy metals $(\mathrm{mg} / \mathrm{kg})$} \\
\hline & & $\mathrm{Cr}$ & $\mathrm{Cu}$ & As & $\mathrm{Cd}$ & $\mathrm{Pb}$ \\
\hline \multirow{3}{*}{ DC } & Mean & 125.001 & 52.193 & 16.847 & 0.925 & 25.384 \\
\hline & Range & $\begin{array}{c}49.409 \sim \\
269.146\end{array}$ & $\begin{array}{c}28.488 \sim \\
92.193\end{array}$ & $\begin{array}{c}10.724 \sim \\
20.634\end{array}$ & $0.662 \sim 1.241$ & $\begin{array}{c}15.386 \sim \\
41.941\end{array}$ \\
\hline & Mean & 118.804 & 65.156 & 17.478 & 0.718 & 27.710 \\
\hline \multirow[t]{2}{*}{ BSH } & Range & $\begin{array}{c}45.683 \sim \\
233.186\end{array}$ & $\begin{array}{c}29.708 \sim \\
114.828\end{array}$ & $\begin{array}{c}11.054 \sim \\
24.087\end{array}$ & $0.576 \sim 0.982$ & $\begin{array}{c}15.864 \sim \\
38.802\end{array}$ \\
\hline & Mean & 117.922 & 115.663 & 23.409 & 2.017 & 71.134 \\
\hline $\mathrm{CZB}$ & Range & $\begin{array}{c}43.380 \sim \\
226.282\end{array}$ & $\begin{array}{c}53.168 \sim \\
238.150\end{array}$ & $\begin{array}{c}15.131 \sim \\
33.169\end{array}$ & $0.733 \sim 5.667$ & $\begin{array}{c}28.832 \sim \\
169.158\end{array}$ \\
\hline $\begin{array}{l}\text { Yangtze } \\
\text { River }\end{array}$ & Range & $\begin{array}{c}105.401 \\
84.693 \sim \\
128.878\end{array}$ & $\begin{array}{c}137.692 \\
90.310 \sim \\
227.708\end{array}$ & $\begin{array}{c}21.774 \\
16.245 \sim \\
26.389\end{array}$ & $0.855 \sim 1.197$ & $\begin{array}{c}60.549 \\
52.612 \sim \\
77.455\end{array}$ \\
\hline \multicolumn{2}{|c|}{$\begin{array}{l}\text { The Yangtze River } \\
\text { Background }^{[21]}\end{array}$} & 52.3 & 21.5 & 7.6 & 0.15 & 21.4 \\
\hline \multicolumn{2}{|c|}{$\begin{array}{l}\text { The first-rate standard } \\
\text { of the Soil } \\
\text { Environmental Quality }\end{array}$} & $\leq 90$ & $\leq 35$ & $\leq 15$ & $\leq 0.20$ & $\leq 35$ \\
\hline
\end{tabular}


Spatial and temporal variation characteristics of heavy metals in sediments. The average contents of the heavy metals in sediments of Daning river and Yangtze river are shown in Fig.2. Results showed that the contents of all the five heavy metals $(\mathrm{Cr}, \mathrm{Cu}, \mathrm{As}, \mathrm{Cd}, \mathrm{Pb})$ were higher than the background values during most of the time. The trends of the five heavy metal contents in sediments of Daning river showed similar seasonal variances with an increasing trend during drainage period, and decreased gradually during impounding period, and then remained stable during high water level period. After the drainage period, $\mathrm{Cr} 、 \mathrm{Cu} 、 \mathrm{As} 、 \mathrm{Cd}$ and $\mathrm{Pb}$ all reached the maximum value, 242.871, $136.784,25.247,2.494$ and $78.614 \mathrm{mg} / \mathrm{kg}$, respectively, which were about 3.04, 2.36, 1.46, 3.14 and 2.71 times of other periods. The seasonal differences of $\mathrm{Cr}$ and $\mathrm{Cd}$ were more evident. Spatially, the contents of heavy metal exhibited a tendency to increase from the upstream to downstream. Higher values always occurred at $\mathrm{CZB}$, while lower values occurred at DC. The spatial differences and accumulated trends in the contents were more noticeable of $\mathrm{Cu}, \mathrm{As}$ and $\mathrm{Pb}$, and the contents at $\mathrm{CZB}$ were 1.78, 1.34, 2.57 times of those at $\mathrm{BSH}$ and 2.21, 1.39, 2.80 times of those at DC. For Cr, the spatial distributions of the contents were more uniform. The changes of the heavy metal contents in sediments of Yangtze River were relatively stable with less fluctuation than those of Daning river. In addition, the heavy metal contents of Yangtze River were higher than those of Daning river within the year, except the period after drainage.

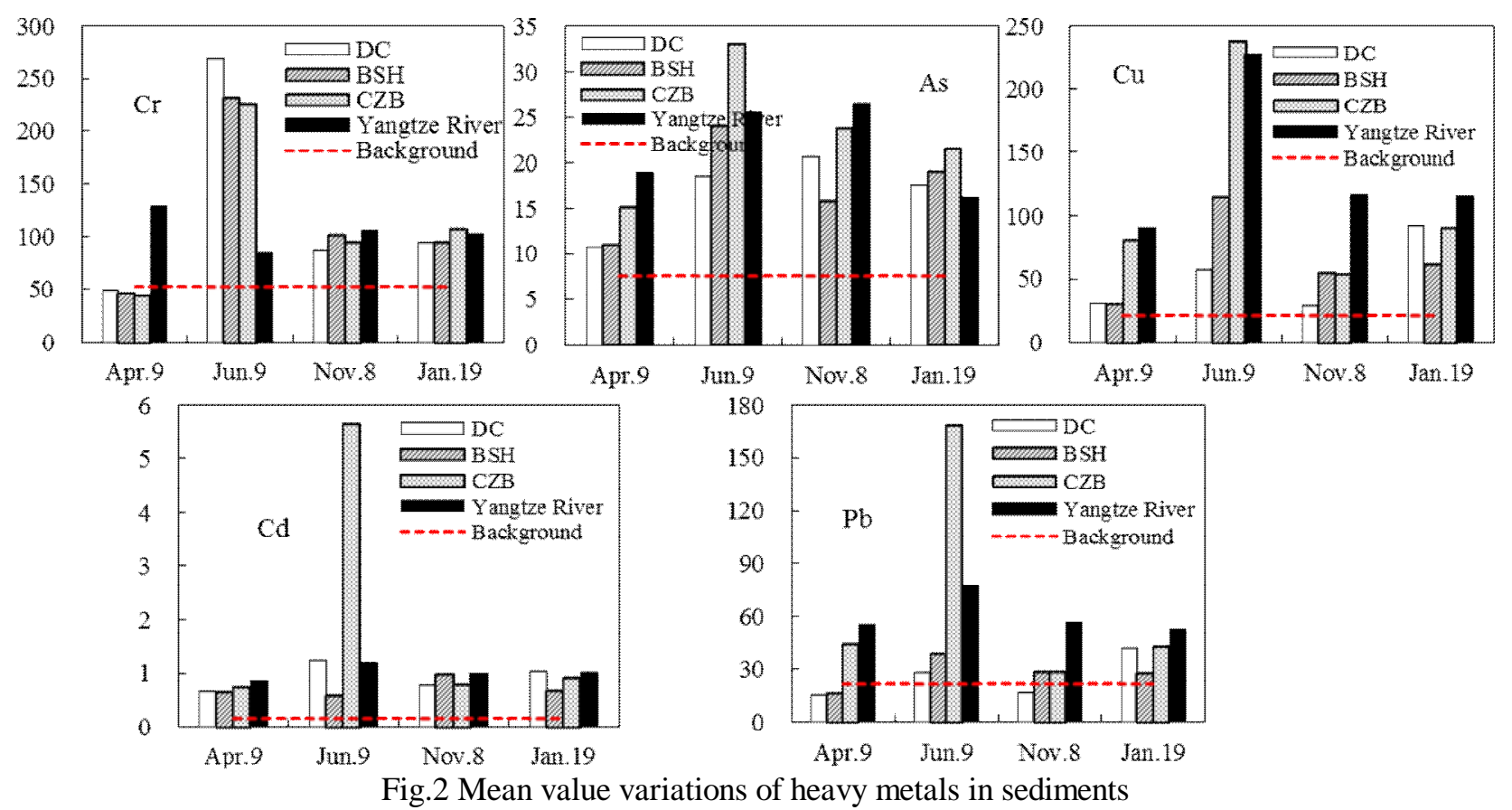

Vertical and temporal variation characteristics of heavy metals in sediment. The vertical (surface layer: 0 5cm, middle layer: 5 10cm, bottom layer: $10 \sim 15 \mathrm{~cm}$ ) and temporal distribution of heavy metals contents in sediments of Daning river and Yangtze River are shown in Fig.3. The heavy metal contents exhibited an increasing trend from the surface layer to bottom layer during the drainage period and the high water level period, but the increasing extents were different. The contents of $\mathrm{Cd}$ and $\mathrm{Pb}$ were significantly different between the surface layer and the bottom layer, and the contents in the bottom layer were about 1.50 and 1.86 times of those in the surface layer. Element As had the lowest accumulate rate, and the content in the bottom layer was about 1.26 times of that in the surface layer. While each heavy metal showed decreasing trend from the surface layer to bottom layer during the impounding period. In particular, the vertical variations in the contents were most noticeable of $\mathrm{Cu}$ and $\mathrm{Pb}$, and the contents in the surface layer were about 2.25 and 2.62 times of those in the bottom layer. While the As contents showed no obvious difference between the surface layer and the bottom layer. 
These indicated that the vertical variations of $\mathrm{Cd}$ and $\mathrm{Pb}$ contents were more sensitive to the operation of Three Gorges reservoir, while As was less affected.

The contents of heavy metal in sediments of Daning river increased during the drainage period, which indicated that there were large amount of anthropogenic inputs during this period. What's more, $\mathrm{Cr}, \mathrm{Cu}$ and $\mathrm{Pb}$ showed more obvious increasing trend. However, the vertical changes of the heavy metal were not obvious in this period. In the impounding period, the contents of heavy metal decreased, and exhibited a decreasing trend from the surface to the bottom. In the high water level period, the contents of heavy metal increased, and gradually migrated to the bottom layer. The most affected elements were $\mathrm{Cr}, \mathrm{Cu}$ and $\mathrm{Pb}$.

Most noteworthy, 1) the heavy metal contents increased during the drainage period, but the vertical changes were not obvious in this period. 2) In addition, the contents decreased during the impounding period, and the vertical distribution characteristics showed obvious changes. 3) In the high water level period, the heavy metals gradually migrated to the bottom layer, and the vertical distribution characteristics returned to the state before the impounding period. For the vertical distribution of heavy metals, the surface layer was most affected by the hydrodynamic characteristics changes after the Three Gorges reservoir operation and the influence of human activities. For each heavy metal, $\mathrm{Cd}$ and $\mathrm{Pb}$ were the most disturbed by the external environment.

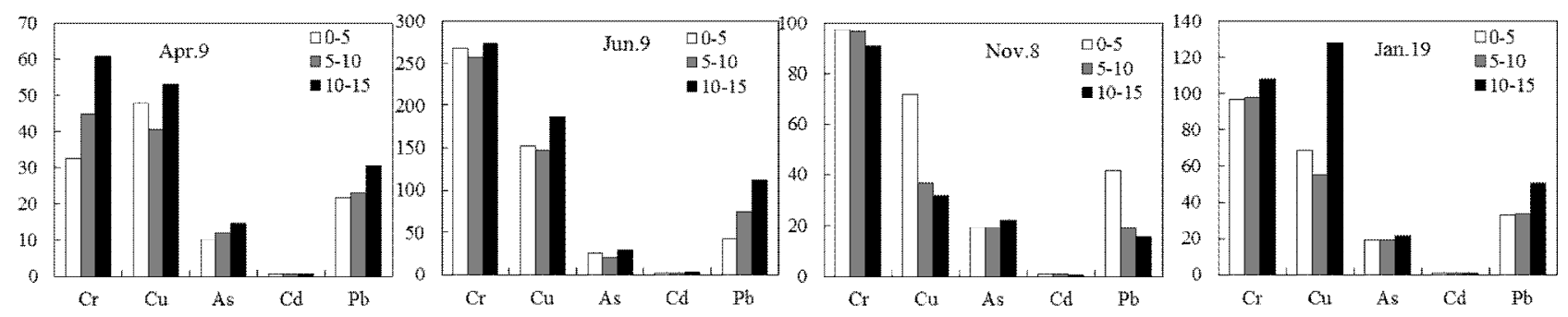

Fig.3 Vertical variations of mean value of heavy metals in Daning River sediments

Assessment of heavy metal pollution. Individual and integrated potential ecological risk index $\left(E^{i}\right.$ and $R I$ ) for heavy metals in sediments of Daning River and the Yangtze River are shown in Table 3. The results showed that potential ecological risk level for heavy metals in sediments decreased in the order: $\mathrm{Cd}>\mathrm{As}>\mathrm{Cu}>\mathrm{Pb}>\mathrm{Cr}$. Cd posed the highest potential ecological risk with a mean $E r^{i}$ value of 244. And the $E r^{i}$ value reached 1133 in the CZB site, which was even greater than the high level of pollution degree. All the individual potential ecological risk of heavy metals were at the low degree $\left(E r^{i}\right.$ were lower than 40), except for Cd. According to the potential ecological risk index (RI), the values were higher in the period after drainage period and the impounding period. The RI values in DC, BSH, CZB and Yangtze River ranged from 193 to 302, from 192 to 241, from 207 to 1281, and from 278 to 347. The potential ecological risk index of heavy metals showed an obvious increasing trend from upstream to downstream, which were consistent with the results of $\mathrm{AN}^{[22]}$. Among all the sites, $\mathrm{CZB}$ and Yangtze River posed high risk level, with the highest RI values of 1281 and 347. Overall, Cd was the main contributor to the ecological risk. The time period and region of potential ecological risk of $\mathrm{Cd}$ was consistent with the integrated potential ecological risk of the Daning river. The integrated potential ecological risk reached above the moderate level affected by the ecological risk of $\mathrm{Cd}$. Therefore, the potential ecological risk reached high level in the period after drainage and the impounding period.Spatially, the potential ecological risk were higher at CZB and Yangtze River. 
Table.3 Risk index of heavy metals in sediments of Daning River

\begin{tabular}{|c|c|c|c|c|c|c|c|}
\hline \multirow{2}{*}{$\begin{array}{c}\text { Monitoring } \\
\text { sections }\end{array}$} & \multirow{2}{*}{$\begin{array}{c}\text { Scheduling } \\
\text { period }\end{array}$} & \multicolumn{5}{|c|}{$E_{r}^{i}$} & \multirow{2}{*}{ RI } \\
\hline & & $\mathrm{Cr}$ & $\mathrm{Cu}$ & As & $\mathrm{Cd}$ & $\mathrm{Pb}$ & \\
\hline \multirow{4}{*}{$\mathrm{DC}$} & Before drainage & 2 & 7 & 14 & 132 & 4 & 159 \\
\hline & After drainage & 10 & 13 & 24 & 248 & 7 & 302 \\
\hline & Impounding period & 3 & 7 & 27 & 152 & 4 & 193 \\
\hline & High water level period & 4 & 21 & 23 & 208 & 10 & 266 \\
\hline \multirow{4}{*}{$\mathrm{BSH}$} & Before drainage & 2 & 7 & 15 & 129 & 4 & 157 \\
\hline & After drainage & 9 & 27 & 32 & 115 & 9 & 192 \\
\hline & Impounding period & 4 & 13 & 21 & 196 & 7 & 241 \\
\hline & High water level period & 4 & 14 & 25 & 134 & 6 & 183 \\
\hline \multirow{4}{*}{$\mathrm{CZB}$} & Before drainage & 2 & 19 & 20 & 147 & 10 & 198 \\
\hline & After drainage & 9 & 55 & 44 & 1133 & 40 & 1281 \\
\hline & Impounding period & 4 & 12 & 31 & 153 & 7 & 207 \\
\hline & High water level period & 4 & 21 & 28 & 181 & 10 & 244 \\
\hline \multirow{4}{*}{$\begin{array}{l}\text { Yangtze } \\
\text { River }\end{array}$} & Before drainage & 5 & 21 & 25 & 171 & 13 & 235 \\
\hline & After drainage & 3 & 53 & 34 & 239 & 18 & 347 \\
\hline & Impounding period & 4 & 27 & 35 & 199 & 13 & 278 \\
\hline & High water level period & 4 & 27 & 21 & 201 & 12 & 265 \\
\hline
\end{tabular}

\section{Discussion}

The enrichment characteristics of heavy metals in sediments of Daning River. The contents of heavy metals in sediments of Daning river showed an increasing trend along the flow direction, with the high value occurred at the entrance area of the Yangtze River. The heavy metals exhibited a cumulating trend along the flow direction of Daning River, which indicated that the heavy metals pollution affected by human was more obvious in the river near the city. This was consistent with the results in Xiangxi river and Daning river and Modaoxi river that the heavy metals contents exhibited an increasing trend from upstream to downstream ${ }^{[2]}$. According to the river sedimentary differentiation principle, the significantly increasing of water level may result in the decreasing of water flow velocity and increasing of water residence time. As a result, this accelerated the deposition of suspended particles in the tributaries of the downstream. Therefore, the heavy metals which were easy to be absorbed onto the fine particulates and organics in water body deposited on the river bottom. Especially in the estuary, heavy metals deposited on the bottom along with the suspended particulates and organics due to the weakness of hydrodynamic conditions, which consequently led to dramatic increase of heavy metal contents ${ }^{[23-26]}$. These contributed to higher heavy metals contents in sediments from downstream than from upstream ${ }^{[27]}$. For the Yangtze River, the background values of heavy metals were high due to the main soil types was limestone soil parent material in the bank of downstream ${ }^{[28]}$. Moreover, after the water level raised up to $175 \mathrm{~m}$, the soil rock were dissolved and carried large amounts of heavy metals into the reservoir, which was the main reason for the increasing of heavy metal contents in the downstream of the Yangtze River mainstream ${ }^{[15,29,30]}$. What's more, the heavy metals except Cr were significantly correlated at 0.01 level, which suggested that they may have the similar sources (Table. 4). The four elements $(\mathrm{Cu}, \mathrm{As}, \mathrm{Cd}$ and $\mathrm{Pb})$ were more likely accumulated at the same time in sediments of Daning River. It was clear that there was potential pollution risk in the load of heavy metals in sediments of Daning River.

Table.4 Correlation coefficient matrices between heavy mental contents in sediments of Daning River

\begin{tabular}{cccccc}
\hline & $\mathrm{Cr}$ & $\mathrm{Cu}$ & $\mathrm{As}$ & $\mathrm{Cd}$ & $\mathrm{Pb}$ \\
\hline $\mathrm{Cr}$ & 1.000 & 0.346 & $0.529^{*}$ & 0.471 & 0.407 \\
$\mathrm{Cu}$ & & 1.000 & $0.746^{* *}$ & $0.678^{* *}$ & $0.888^{* *}$ \\
$\mathrm{As}$ & & 1.000 & $0.635^{* *}$ & $0.742^{* *}$ \\
$\mathrm{Cd}$ & & & 1.000 & $0.916^{* *}$ \\
$\mathrm{~Pb}$ & & & & 1.000 \\
\hline
\end{tabular}

**Correlation is significant at the 0.01 level.

* Correlation is significant at the 0.05 level. 
Compared with the background value of sediment in Yangtze River, the contents of $\mathrm{Cr}, \mathrm{Cu}, \mathrm{As}, \mathrm{Cd}$ and $\mathrm{Pb}$ in sediments were 2.23, 4.31, 2.61, 7.79, 2.16 times of the background value, respectively. In particular, the enrichment extent of $\mathrm{Cd}$ and $\mathrm{Cu}$ were the highest, which indicated that there were large amounts of exogenous inputs of $\mathrm{Cd}$ and $\mathrm{Cu}$ of in Daning River within recent years. Compared with the contents of heavy metal in Daning River in 2010 and in other tributaries of Yangtze River ${ }^{[22,31]}$, the elements including $\mathrm{Cr}, \mathrm{Cu}, \mathrm{Cd}, \mathrm{Pb}$ showed a significantly increasing trend. The average contents were $120.576,77.671,1.22,41.409 \mathrm{mg} / \mathrm{kg}$, respectively, which were $1.44,1.77,1.97,1.28$ times of those in 2010 , respectively. Whereas the contents of As $(19.245 \mathrm{mg} / \mathrm{kg})$ exhibited a tendency to decrease, was 0.64 times of that in 2010. This indicated that the human activities including industrial production of coastal city and domestic sewage discharge caused a certain influence on the heavy metals pollution in sediments with the discharging and the depositing of heavy metals onto sediments of Daning river. The pollution situation of heavy metals in sediment of Daning river should not be underestimated, especially the $\mathrm{Cr}, \mathrm{Cu}, \mathrm{Cd}$ and $\mathrm{Pb}$ pollution with increasing trend recently.

Effects of different operation schedule on heavy metals pollution in sediment of tributaries. Daning river is located in the hinterland of the Three Gorges reservoir area. Therefore, the hydrological and water environmental characteristics have significantly changed under the influence of the Three Gorges reservoir operation ${ }^{[2,3]}$. As a natural record of the response of the lake environment to human activities, the sediment cores could reflect the process of environmental evolution in the basin and the impact of human activities in different stages ${ }^{[32,33]}$. For the tributaries of the Three Gorges reservoir, the migration and distribution of heavy metals in the sediment cores were mainly affected by sedimentation of reservoir and transportation of water flow under the influence of different hydrodynamic conditions. According to the results of correlation analysis, $\mathrm{Cu}, \mathrm{As}, \mathrm{Cd}$ and $\mathrm{Pb}$ may have the similar sources. Therefore, this study attempted to analyze the migration and distribution characteristics of $\mathrm{Cu}, \mathrm{As}, \mathrm{Cd}$ and $\mathrm{Pb}$ elements in sediment cores of Daning river at different operation stages of Three Gorges Reservoir, and to reflect the influence of the Three Gorges reservoir operation on the heavy metals in sediments of Daning river. The results showed that the vertical distribution and longitudinal distribution characteristics of heavy metals in sediments with different hydrology and hydrodynamics conditions under the influence of intrusion in different operation stages were significantly different. From the longitudinal distribution point of view, the heavy metals at CZB were strongly influenced by the Yangtze river at all stages because the site was located near the estuary. The heavy metals at BSH were influenced by the Yangtze river during the period after drainage and impounding period and high water level period, while during the period before drainage, the heavy metals were affected by the upstream. However, the heavy metals at DC were relatively less likely to be affected by the Yangtze river for the site located near upstream. From the vertical distribution point of view, the heavy metals in each layer were influence by the Yangtze river during the drainage and impounding period, especially the surface layer during the impounding period. From the content of elements point of view, the contents of heavy metals reached the highest value in the period after drainage at all sections.

As shown in Fig.4, the heavy metal contents in Yangtze River were the highest during the period before drainage ( 9 April), followed by those in the backwater region of Daning river, while those in upstream were the lowest. The distribution features and contents of heavy metals in the CZB section were similar to Yangtze River, while those in the BSH section and DC section were more similar. It can be inferred that the area affected by the intrusion of Three Gorges reservoir in the period before the drainage was the estuary of Daning river, however, the heavy metals in the BSH section and DC section were more affected by the upstream.

In the period after drainage (9 June), the distribution features and contents of heavy metals in the BSH section and CZB section were similar to Yangtze river, which indicated that the area affected by the intrusion of Three Gorges reservoir extended to the BSH section. Most noteworthy, the heavy metal contents were significantly higher than those in the period before drainage, and the contents in the CZB section were higher than those in Yangtze river. This indicated that there might be other possible sources in the Daning river, especially the $\mathrm{CZB}$ section. The main reason was that during the 
drainage period (from April to June) Daning river was in the flood season, and the rainfall occurred frequently. Therefore, soil erosion carries a large amount of silt and clay minerals, which lead to the increase of the content of suspended particulate matter in water ${ }^{[34]}$. Meanwhile, the residents in the basin began to cultivate, and some of the soils of water level fluctuating zone were turned into temporary cultivated land when the water lever at the depth of $145 \mathrm{~m}$,. Therefore, the heavy metals from the point source and non-point source of the shore accumulated in the soils of water level fluctuating zone ${ }^{[35]}$. With frequency occurrence of rainfall, many heavy metal contaminations entered into the backwater of Daning river ${ }^{[14,35]}$ and induced the heavy metal contents in the water to increase. In addition, the heavy metal elements were absorbed by suspended particulate matters and organic matters, and then deposited to the bottom. This resulted in the increasing of heavy metal contents in the sediment after drainage. Research showed that the pesticide, fertilizer and organic fertilizer applied in the shore soil and the pollutant discharged by human production and life were the main sources of heavy metals in the area near $\mathrm{CZB}^{[35]}$, and were the main reasons for the increasing of $\mathrm{Cu}, \mathrm{As}, \mathrm{Cd}$ and $\mathrm{Pb}$ in the period after drainage. However, the distribution of $\mathrm{Cr}$ exhibited decreasing trend from upstream to downstream after drainage, which was mainly because of the recharge from upstream.

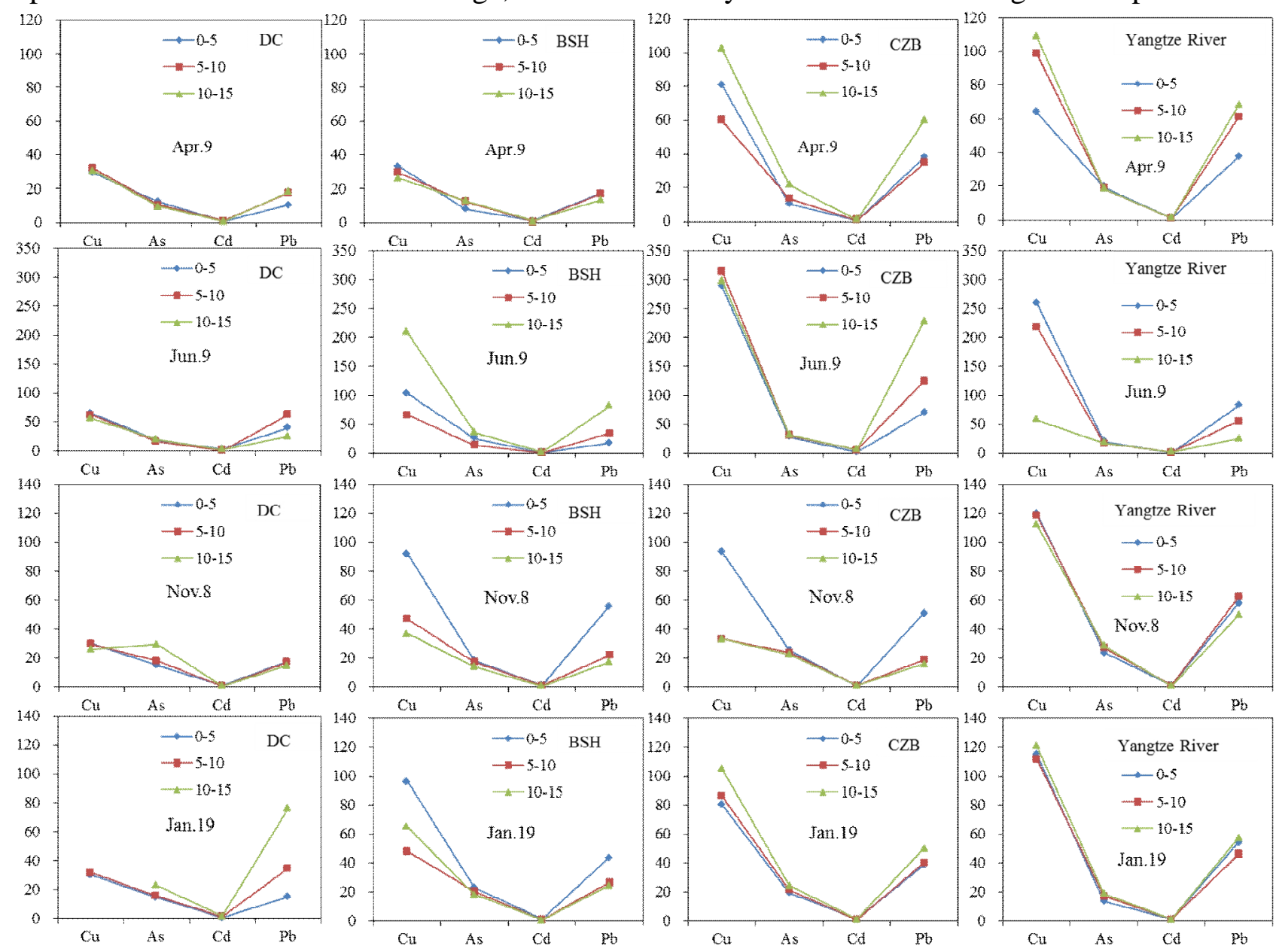

Fig.4 Temporal and spatial and vertical distribution characteristics of heavy metals in sediments of Daning River and Yangtze River

In the impounding period ( 8 November), the distribution features and contents of heavy metals in the BSH section and CZB section were similar to Yangtze River, which indicated that the heavy metals of the surface layer in the area from the middle reach of the backwater to the estuary were more affected by the intrusion of Yangtze River. While the heavy metals of the middle layer were relatively unaffected. During this period, the heavy metal contents decreased. The main reason was that in the flood season (from July to August) the reservoir vacated capacity under the operation schedule, which promoted the transition process from slow flow to rapid flow of the river backwater, and increased the flow velocity. Therefore, the silt and organic matter in the sediment were carried by water flow under 
the influence of flow scouring, so the heavy metals in the Daning river transported to the Yangtze river. Therefore, the heavy metals contents in the Daning river decreased.

In the high water level period (19 January), the water level remained stable, so the contents of heavy metals in the sediments tended to stable, and the vertical distribution of heavy metals was gradually mixed evenly. In addition, the distribution features and contents of heavy metals in the BSH section and CZB section were similar to Yangtze River, but had lower similarity to the DC section. This indicated that the range and extent of the Yangtze River impact on the heavy metals in the sediment of Daning river during this period were similar to those during the impounding period. However, the heavy metals in the DC section were not affected by the Yangtze River during the whole year.

\section{Conclusions}

1. The mean contents ranges of five 5 kinds heavy metals $(\mathrm{Cr}, \mathrm{Cu}, \mathrm{As}, \mathrm{Cd}, \mathrm{Pb})$ in sediments of the study area were: 43.380- 269.146, 28.488- 238.150, 10.724- 33.168, 0.576- 5.667, 15.386-169.158 mg/kg. The average contents of $\mathrm{Cr}, \mathrm{Cu}, \mathrm{As}, \mathrm{Cd}$ and $\mathrm{Pb}$ in the samples were $116.782 \mathrm{mg} / \mathrm{kg}, 92.676 \mathrm{mg} / \mathrm{kg}$, $19.877 \mathrm{mg} / \mathrm{kg}, 1.168 \mathrm{mg} / \mathrm{kg}, 46.194 \mathrm{mg} / \mathrm{kg}$, respectively, ranking in decreasing order as follows, $\mathrm{Cr}>$ $\mathrm{Cu}>\mathrm{Pb}>\mathrm{As}>\mathrm{Cd}$. Compared with the background values of the Yangtze river, the contents exceed by about 1.23, 3.31, 1.61, 6.79, 1.16 times, respectively, and $\mathrm{Cd}, \mathrm{Cu}$ exceed most among them.

2. The potential ecological risk level of heavy metal in sediments decreased in the order: $\mathrm{Cd}>\mathrm{As}>$ $\mathrm{Cu}>\mathrm{Pb}>\mathrm{Cr}$, and $\mathrm{Cd}$ was the chief contributor. Sediments of Daning river presented Cd pollution with varying degrees, ant the integrated potential ecological risk reached moderate level. In particular, the potential ecological risks were higher in the period after drainage and the impounding period, especially at the sections of CZB and Yangtze River.

3. The contents of heavy metals in sediments of Daning river showed an increasing trend along the flow direction, with the high values occurred at the entrance area of the Yangtze River. The heavy metals exhibited a cumulating trend along the flow direction of Daning River, which indicated that the heavy metals pollution affected by human activities was more obvious in the river near the city. The heavy metals except $\mathrm{Cr}$ may have the similar sources. And there was potential pollution risk in the load of heavy metals in sediments of Daning River. In the period after drainage, the heavy metal contents were highest within the year, and decreased during impounding period. The results caused by following reasons: 1) During the flood season, the rainfall occurred frequently in Daning river, and proportion of arable land in Daning river basin was high. Therefore, the heavy metals from the point source and non-point source of the shore accumulated in the soils of water level fluctuating zone. With frequency occurrences of rainfall, many heavy metal contaminations entered into the backwater of Daning river and induced the heavy metals contents to increase after drainage. 2)In flood season (from July to August) the reservoir vacated capacity under the operation schedule, which promoted the transition process from slow flow to rapid flow of the river backwater, and increased the flow velocity. Therefore, the silt and organic matter in sediments were carried by water flow under the influence of flow scouring, so the heavy metal contents of Daning river decreased.

4. The vertical distribution characteristics shown as follow: 1) the contents of the heavy metal in sediments of Daning river and Yangtze River increased during the drainage period, but the vertical distribution changes were not significant in this period. 2) In addition, the contents decreased slightly during the impounding period, and the vertical distribution characteristics showed obvious changes. 3) In the high water level period, the heavy metals gradually migrated to the bottom layer, and the vertical distribution characteristics returned to the state before the impounding period. For the vertical distribution of heavy metals, the surface layer was affected by the hydrodynamic characteristics changes after the Three Gorges reservoir operation and the influence of human activities, mostly. For each heavy metal, $\mathrm{Cd}$ and $\mathrm{Pb}$ were the most disturbed by the external environment.

5. The vertical distribution and longitudinal distribution characteristics of heavy metals in the sediment were significantly different under the different operation of the Three Gorges reservoir. From the longitudinal distribution point of view, the heavy metals at CZB were strongly influenced by the 
Yangtze River at all stages because the section was located near the estuary. The heavy metals at BSH were influenced by the Yangtze River during the period after drainage and impounding period and high water level period, while during the period before drainage, the heavy metals were affected by the upstream. However, the heavy metals at DC were relatively less likely to be affected by the Yangtze River for the section located near upstream. From the vertical distribution point of view, the heavy metals in each layer were influence by the Yangtze River during the drainage and impounding period, especially the surface layer during the impounding period.

\section{Acknowledgements}

The research was supported by National Sciences and Technology Major Project (No. 2012ZX07503-002) funded by Ministry of Science and Technology of China.

\section{References}

[1] Y Wang, Z Y Shen, L J Hu, et al. Absorption and release of phosphorus from sediments from the main branches of the Three Gorges Reservoir. Acta Scientiae Cirumstantiae. 2008, 28(8): 1654-1661. (in Chinese)

[2] N Jiao, Y Zhang, Y Zeng, et al. Ecological anomalies in the East China Sea: Impacts of the three gorges dam?. Water Research. 2007, 41(6): 1287-1293.

[3] H Zeng, L Song, Z Yu, et al. Distribution of phytoplankton in the Three-Gorge Reservoir during rainy and dry seasons. Science of the Total Environment. 2006, 367(2): 999-1009.

[4] G Yang. Experimental study on contaminant release of flooded soils in Three Gorges Reservoir. Journal of Soil and Water Conservation. 2004, 18(1): 111-114. (in Chinese)

[5] Y Y Qin, C K M Leung, A O W Leung, et al. Persistent organic pollutants and heavy metals in adipose tissues of patients with uterine leiomyomas and the association of these pollutants with seafood diet, BMI, and age. Environmental Science and Pollution Research. 2010, 17(1): 229-240.

[6] W Zhang, H Feng, J Chang, et al. Heavy metal contamination in surface sediments of Yangtze River intertidal zone: an assessment from different indexes. Environmental Pollution. 2009, 157(5): 1533-1543.

[7] Kumar Sharma R, Agrawal M, Marshall F. Heavy metal contamination of soil and vegetables in suburban areas of Varanasi, India. Ecotoxicology and environmental safety. 2007, 66(2): 258-266.

[8] Mays P A, Edwards G S. Comparison of heavy metal accumulation in a natural wetland and constructed wetlands receiving acid mine drainage. Ecological Engineering. 2001, 16(4): 487-500.

[9] Z G Yao, Z Y Bao, P Gao, et al. Environmental geochemistry of heavy metals in sediments of Dongting Lake. Geochimica. 2006, 35(6): 629-638. (in Chinese)

[10] Q Li. Study on arsenic, lead, and chromium toxic heavy metals in Three Gorges Reservoir region after impoundment. Chongqing: Southwest University, 2006. (in Chinese)

[11] Y B Lv, Z Y Gong, J Lian, et al. Status of water quality in the Three Gorges after the water storage period. Research of Environmental Sciences. 2007, 20(1): 1-6. (in Chinese)

[12] J Zhao, Z G Yu, H T Chen, et al. Distributions of dissolved heavy metals in the typical backwater regions of the Three Gorges Reservoir. Journal of Hydroecology. 2009, 2(2): 9-14. (in Chinese)

[13] X B Ran, Z G Yu, H T Chen, et al. Distributions of dissolved inorganic mercury in the lower part of the Three Gorges Reservoir. Environmental Sciences. 2008, 29(7): 1775-1779. (in Chinese)

[14] F Y Ji, T J Wang, X B Hu, et al. Movement and transformation of heavy metals in water-sediment in water level fluctuating zone of Three Gorges Reservoir area. Environmental Sciences. 2009, 30(12):3481-3487. (in Chinese)

[15] T Q Pei, L A Wang, Y Han, et al. Distribution characteristics form soil profile heavy metal of water level fluctuating zone in Three Gorges Reservoir area. Research of Environmental Sciences. 2008, 21(5): 72-78. (in Chinese) 
[16] L A Wang, J H Yue, Huang C, et al. Contamination characteristic analysis of heavy metals in MSW dumped in Three Gorges Region. Acta Scientiae Circumstantiae. 2006, 26(2): 246-251. (in Chinese)

[17] T J Wang, X B Hu, F Y Ji, et al. Chemical fraction composition characteristics of heavy metals and effects on water quality in submerged soil of Three Gorges Reservoir area. Research of Environmental Sciences. 2010(2): 158-164.(in Chinese)

[18] Y W Fu, M J Chen, J S Qi. Experimental study on migration of heavy metals in soil-water system of water level fluctuation zone. Water Resources Protection. 2008, 24(5): 8-11. (in Chinese)

[19] J K Wang, B Gao, H D Zhou, et al. Heavy metals pollution and its potential ecological risk of the sediment in Three Gorges Reservoir during its impounding period. Environmental Sciences. 2012, 33(5): 1693-1699. (in Chinese)

[20] Tuna A L, Yilmaz F, Demirak A, et al. Sources and distribution of trace metals in the saricay stream basin of southwestern turkey. Environmental monitoring and assessment. 2007, 125(1-3): 47-57.

[21] Merian E. Metals and their compounds in the environment: occurrence, analysis and biological relevance. VCH Verlagsgesellschaft $\mathrm{mbH}, 1991$.

[22] L H An, Y Q Zhang, B H Zheng, et al. Characteristics of heavy metal pollution in Daninghe river and Modaoxi river of Three Gorges Reservoir areas. Environmental Science. 2012, 33(8): 2592-2598. (in Chinese)

[23] Almeida C M R, Mucha A P, Vasconcelos M T S. Influence of the sea rush Juncus maritimus on metal concentration and speciation in estuarine sediment colonized by the plant. Environmental science \& technology. 2004, 38(11): 3112-3118.

[24] Bryan G W, Langston W J. Bioavailability, accumulation and effects of heavy metals in sediments with special reference to United Kingdom estuaries: a review. Environmental Pollution. 1992, 76(2): 89-131.

[25] L H Dong, Y N Li, S Y Chang, et al. Fraction distribution and risk assessment of heavy metals in sediments. Journal of Tianjin University. 2009, 42(12): 1112-1117. (in Chinese)

[26] E F Liu, J Shen, L Y Yang, et al. Chemical fractionation and pollution characteristics of heavy metals in the sediment of Nansihu Lake and its main inflow river, China. Environmental Sciences. 2007, 28(6): 1377-1383. (in Chinese)

[27] S Y Yin, B F Lou, H Liu, et al. Analysis of water quality of the Yangtze river within the Three Gorges Reservoir area during construction period. Resources and Environment in the Yangtze Basin. 2011, 20(3): 305-310. (in Chinese)

[28] T J Wang, Q W Yang, X L Liu, et al. Distribution of soluble heavy metal concentration in the water body in Three Gorges Reservoir after its $172 \mathrm{~m}$ impoundment. Resources and Environment in the Yangtze Basin. 2013, 22(9). (in Chinese)

[29] X Zhou, J Zheng, S Zhang, et al. Heavy metals distribution of soils in water level fluctuating zone of the Three Gorges Reservoir. Environment al Monitoring in China. 2007, 22(6): 86-88. (in Chinese)

[30] S J Xu, S Q Wei, D T Xie. Characteristics of heavy metals distribution in cultivated soil in Three Gorges Reservoir area. Journal of Soil and Water Conservation. 2004, 17(4): 64-66. (in Chinese)

[31] S B Xiao, D F Liu, Y C Wang, et al. Characteristics of heavy metal pollution in sediments at the Xiangxi bay of Three Gorges Reservoir. Resources and Environment in the Yangtze Basin. 2011, 20(8): 983-989. (in Chinese)

[32] F X Qi, B H Zheng, J Wan, et al. Pollution of heavy metal in the sample of column of Bohai bay in Tianjin. Ocean Technology. 2004, 23(003): 85-91. (in Chinese)

[33] E F Liu, J Shen, X Q Liu, et al. Characteristics and pollution history of heavy metals and nutrients in sediment of Taihu Lake. Science in China Ser. D Earth Sciences. 2005: 72-80. (in Chinese)

[34] S Zhang, L L Li, Y Zhang, et al. Changes of heavy metals distribution in water body of the Three Gorges Reservoir at 135m water level. Journal of Anhui Agricultural Sciences. 2007, 35(11): 3342-3343. (in Chinese) 
[35] L Zhang, Y W Qin, B H Zheng, et al. Distribution and pollution assessment of heavy metal in the soil of backwater reach from input river of Three Gorges Reservoir. Environmental Science and Technology. 2011, 34(4): 81-85. (in Chinese) 